\title{
Clinic Pathological Profile of Neuroblastoma, Our Experience at Tertiary Care Hospital; Government Medical College Hospital Srinagar J \& K
}

\author{
Zahida Akhter, Shahnawaz Mansoor Shah*, Perveez Ahmad Malik, \\ Showkat Ahmad Kakroo \\ Sher-i-Kashmir Institute of Medical Sciences (SKIMS), Srinagar, India \\ Email: *drnawaz1008@gmail.com
}

Received 29 June 2016; accepted 26 August 2016; published 29 August 2016

Copyright (C) 2016 by authors and Scientific Research Publishing Inc.

This work is licensed under the Creative Commons Attribution International License (CC BY). http://creativecommons.org/licenses/by/4.0/

CC) (i) Open Access

\begin{abstract}
Introduction: Pediatric tumors account for a small proportion of all cancers; amongst them neuroblastoma is the most common solid tumor as well as malignant tumor. They have varied clinical presentation. Recent advances in diagnostic methods and multidisciplinary treatment approach have resulted in early diagnosis, treatment, better prognosis and survival. Aims and Objectives: To study the clinical profile, histopathology, grading and correlate that with clinical diagnosis, efficacy of various investigations for early diagnosis, and management of neuroblastoma in our hospital. Material and Methods: A total of nine patients of neuroblastoma were studied from May 2013 to January 2015. All the nine patients were operated. Neuroblastoma was staged according to the International Neuroblastoma Staging system. Follow-up was carried in all the patients. Results: Two patients in our study were Stage 1, two were Stage $2 \mathrm{~A}$ and 5 patients were Stage 4S. In Stage 1, pre-operative chemotherapy was not given. Tumor was excised in toto. Post-operatively, no adjuvant therapy was given. Patients are alive till date. In Stage $2 \mathrm{~A}$, patients were operated and received post-operative chemotherapy. One patient is alive and disease-free. Other patient died in post-op. period while on chemotherapy. Patients in Stage $4 S$ were operated after receiving pre-op radiotherapy of 500 - 1000 radians and adjuvant chemotherapy. One patient expired in follow-up while four patients are still alive. We have achieved $100 \%$ survival rate in Stage 1, 50\% in Stage 2 and $80 \%$ in Stage $4 S$.
\end{abstract}

\section{Keywords}

Child Hood Malignancies, Neuroblastoma

\footnotetext{
*Corresponding author.
}

How to cite this paper: Akhter, Z., Shah, S.M., Malik, P.A. and Kakroo, S.A. (2016) Clinic Pathological Profile of Neuroblastoma, Our Experience at Tertiary Care Hospital; Government Medical College Hospital Srinagar J \& K. Surgical Science, 7, 368-373. http://dx.doi.org/10.4236/ss.2016.78053 


\section{Introduction}

Primary abdominal tumors, though relatively rare in children, attract considerable notice because of their serious prognosis, high cost of treatment and emotional and psychological trauma, both to parents and the patient. It is estimated that a child has one in five hundred chances of developing cancer during first fifteen years of life [1]. Cancer remains the leading cause of death, after accident for children 14 years of age and younger [2].

The multidisciplinary approach to the care of oncological patients is essential. Majority of tumors in general and pediatric solid tumors in particular can successfully be managed through an orchestrated team approach.

The importance of pathological evaluation of tumor tissue could not be overlooked as the tumor histology was found to predict outcome.

Abdominal tumors can present with pain, vomiting, constipating or less commonly intestinal obstruction. It is not unusual for a child with abdominal mass to present because a family member notices a protuberant mass. The presentation of cancer in children resembles those of childhood conditions like infections particularly viral infection, urinary tract infection, gastro-esophageal reflex, malnutrition, constipation, lymphadenitis, glomerulonephritis and congenital urinary tract anomalies. Therefore deciding whether a child requires further investigation can be challenging [3].

Recent advances in diagnostic methods and application of vigorous multidisciplinary treatment polices have made marked improvement in treating primary abdominal tumors of childhood, because if diagnosed earlier, these tumors are more responsive to treatment resulting in good survival and prognosis [4].

Neuroblastoma is the most common solid tumor in childhood, as well as most common malignant tumor. 50\% of cases occur in first two years and 75\% occur by 5 years of age. Overall incidence is 10.95 per 1 million children younger than age of 15 years and 27.75 per 1 million children in the age group of $0-4$ years.

\section{Aims and Objectives}

To study the clinical profile of neuroblastoma at our hospital.

To study the efficacy of various investigations this would be helpful for early diagnosis, management and follow-up.

To study the outcome of this tumor after multimodality treatment in these cases in our set up.

\section{Material and Methods}

The work has been undertaken to study the clinico-pathological profile of neuroblastoma in children who presented in the outpatient department of pediatric surgery government medical college Hospital, Srinagar from May 2013 to January 2015.

Records of all the patients admitted and operated up to January 2015 were analyzed and were summoned to attend the follow up clinic. A total of 09 patients were studied. Patients were selected randomly. Patients were followed throughout the study period from May 2013 to Jan 2015.

While evaluating the results of the study, relevant history was taken and examination was done. Routine investigations done included hematological, blood bio-chemistry, urine analysis and chest and abdominal radiographs. Specific investigations included, USG (ultrasonography) abdomen, FNAC (fine needle aspiration cytology) of the swelling, CECT (contrast enhanced computed tomography) abdomen and chest when required, MRI (magnetic resonance imaging), tumor markers, bone marrow biopsy, bone scan.

Post-operative follow up of the patients was done in all patients. The cases of primary abdominal tumors who were not amenable to surgery on clinical grounds or who needed pre or post-operative chemotherapy were planned in consultation with the Department of Medical Oncology SMHS (Shri Maharaja Hari Singh) Srinagar.

The treatment was planned according to stage of disease, clinical examination and investigative workup. The advanced stage disease needed pre-operative chemotherapy which was planned and consulted with oncology department of SMHS Hospital Srinagar. Post-operative treatment was planned as per operative findings, histopathology and presence or absence of residual disease.

Neuroblastoma was staged according to the International Neuroblastoma Staging system.

Post-operative follow up was carried out in all the patients in outpatient clinic of SMHS where a detailed note was made of physical findings with regard to the previous physical status. Investigations like USG or CECT were occasionally done whenever needed in which the presence or absence of residual disease or metastasis was 
noted. Follow up was carried out till the date of compilation of this work and figures are valid up to January 2015.

\section{Observations}

This study included the clinic pathological profile of 9 patients of neroblastoma in pediatric age group that were admitted and managed over a period extending from May 2013 to January 2015 (Tables 1-9).

Table 1. Age distribution of neuroblastoma in pediatric age group.

\begin{tabular}{cc}
\hline Age in years & Neuroblastoma $\mathrm{n}=9$ \\
\hline $0-2$ & $3(33.3 \%)$ \\
$2-4$ & $3(33.3 \%)$ \\
$4-6$ & $2(22.2 \%)$ \\
$6-8$ & $1(11.1 \%)$ \\
\hline
\end{tabular}

Table 2. Symptoms in patients of neuroblastoma in our study.

\begin{tabular}{ccc}
\hline Symptomology & No. of cases & $\%$ age \\
\hline Abdominal swelling & 09 & 100 \\
Pain abdomen & 05 & 55.5 \\
Fever & 06 & 75 \\
Vomiting & 04 & 44.4 \\
Pallor & 06 & 75 \\
Weight loss & 02 & 22.2 \\
Early fatigability & 03 & 33.3 \\
Loss of appetite & 02 & 22.2 \\
Metastatic manifestations & 01 & 11.1 \\
(bladder and bowl incontinence) & & \\
Others & 02 & 22.2 \\
\hline
\end{tabular}

Table 3. USG findings in patients of neuroblastoma in our study.

\begin{tabular}{cc}
\hline Tumor characteristics & $\%$ \\
\hline Solid & $05(55.5 \%)$ \\
Cystic & $02(22.2 \%)$ \\
Loculated & $01(11.1 \%)$ \\
Liver involvement & $02(22.2 \%)$ \\
Spleen involvement & $02(22.2 \%)$ \\
Lymph node status & $06(66.6 \%)$ \\
Ascites & $04(44.4 \%)$ \\
\hline
\end{tabular}

Table 4. CECT findings in patients of neuroblastoma in our study.

\begin{tabular}{cc}
\hline Tumor characteristics & $\%$ \\
\hline Disease localized & $03(75 \%)$ \\
Extent demarcated & $03(75 \%)$ \\
Lymph node involvement & $03(75 \%)$ \\
Metastatic disease & $01(25 \%)$ \\
\hline
\end{tabular}


Table 5. Results of FNAC of accessible mass in patients of neuroblastoma.

\begin{tabular}{cccccc}
\hline Neuroblastoma & No of cases of FNAC & Positive & \% age & Negative & $\%$ age \\
\hline \multicolumn{7}{c}{06} & 04 & 66.6 & 02 & 33.3 \\
\hline Table 6. Results of bone marrow aspiration cytology in patients of neuroblastoma. \\
\hline Neuroblastoma & $\begin{array}{c}\text { No of cases } \\
\text { investigated }\end{array}$ & $\begin{array}{c}\text { Positive for } \\
\text { malignant } \\
\text { cells }\end{array}$ & \%age & Negative & \%age \\
05 & 02 & 40 & 03 & 60 \\
\hline
\end{tabular}

Table 7. Incidence of patients according to International Neuroblastoma Staging System for neuroblastoma in our study $(\mathrm{n}=9)$.

\begin{tabular}{ccc}
\hline International Staging System & No of cases & \% age \\
\hline Stage 1 & 2 & 22.2 \\
Stage 2A & 2 & 22.2 \\
Stage 2B & ND & ND \\
Stage 3 & ND & ND \\
Stage 4 & ND & ND \\
Stage 4S & 5 & 55.5 \\
\hline
\end{tabular}

Table 8. Operative findings in patients of neuroblastoma $(n=9)$.

\begin{tabular}{ccc}
\hline Operative findings & No of cases & $\%$ age \\
\hline $\begin{array}{c}\text { Tumor localized with complete excision and } \\
\text { lymphadenectomy }\end{array}$ & 03 & 33.3 \\
Nodes and tumor margins negative & \\
$\begin{array}{c}\text { Tumor localized with lymph node } \\
\text { negative but incomplete gross excision } \\
\begin{array}{c}\text { Tumor localized, completely excised } \\
\text { but liver metastasis present }\end{array}\end{array}$ & 02 & 22.2 \\
$\begin{array}{c}\text { Tumor localized, completely excised } \\
\text { but with marrow involvement }\end{array}$ & 02 & 22.2 \\
\hline
\end{tabular}

$66.6 \%$ of patients were male and $33.3 \%$ female. $75 \%$ of patients were from rural area and $25 \%$ from urban. Abdominal swelling was the constant finding in all cases of neuroblastoma. Diarrhoea was due to the release of vasoactive intestinal polypeptide. Metastatic manifestation was late presentation of disease.

On physical examination $77.7 \%$ patients had pallor and $11 \%$ had oedema. Distention and visible lump was consistent finding in all the patients, flank fullness in 55.5\%, umbilical shift in $22.2 \%$ and ascites in $22.2 \%$.

$22.2 \%$ patients had hemoglobin below $6 \mathrm{~g} \cdot \mathrm{m} \%, 44.4 \%$ between $6-10 \mathrm{~g} \cdot \mathrm{m} \%$ and $22.2 \%$ had 10.1 and above. All the patients of neuroblastoma underwent surgery in our study.

In our study we studied nine patients of neuroblastoma. Two patients were Stage 1 (22.2\%), two patients were Stage 2A (22.2\%) and 5 patients were Stage 4S (55.5\%) (Figure 1).

\section{Discussion}

Present study was conducted in Pediatric division of Department of Surgery, government medical Hospital, Srinagar. In our study we studied nine cases of neuroblastoma. These patients were staged according to International Staging System of neuroblastoma.

Two patients in our study were Stage 1, two were Stage 2A and 5 patients were Stage 4S. 
Table 9. Adjuvant therapy and follow up in neuroblastoma.

\begin{tabular}{|c|c|c|c|c|c|c|c|}
\hline Stage & $\begin{array}{c}\text { No of } \\
\text { patients }\end{array}$ & $\begin{array}{c}\text { Pre-operative } \\
\text { chemo/radio } \\
\text { therapy }\end{array}$ & $\begin{array}{l}\text { Surgery } \\
\text { done }\end{array}$ & $\begin{array}{l}\text { Post-operative } \\
\text { chemotherapy }\end{array}$ & $\begin{array}{c}\text { Post-operative } \\
\text { radiotherapy }\end{array}$ & $\begin{array}{l}\text { Disease free } \\
\text { survival }\end{array}$ & $\begin{array}{c}\text { \%age } \\
\text { disease free } \\
\text { survival }\end{array}$ \\
\hline 1 & 2 & Not given & $\begin{array}{l}\text { Done in } \\
\text { both }\end{array}$ & No & No & $\begin{array}{l}\text { Both are alive } \\
\text { and disease } \\
\text { free }\end{array}$ & 100 \\
\hline $2 \mathrm{~A}$ & 2 & Not given & $\begin{array}{l}\text { Done in } \\
\text { both }\end{array}$ & $\begin{array}{c}\text { Vincristine, } \\
\text { Cyclophosphamide, } \\
\text { Cisplatin, } \\
\text { Doxorubicin, } \\
\text { Etoposide. }\end{array}$ & No & $\begin{array}{l}\text { One patient } \\
\text { died in } \\
\text { post-operative } \\
\text { period, one } \\
\text { still alive }\end{array}$ & 50 \\
\hline $4 \mathrm{~S}$ & 5 & $\begin{array}{l}\text { Pre-operative } \\
\text { radiotherapy } \\
500 \text { - } 1000 \\
\text { rads }\end{array}$ & Done in all & $\begin{array}{c}\text { Cisplatin, } \\
\text { Cyclophosphamide } \\
\text { Adriamycin, } \\
\text { Decarbazine }\end{array}$ & No & $\begin{array}{l}\text { Four patients } \\
\text { alive, } 1 \text { died }\end{array}$ & 80 \\
\hline
\end{tabular}

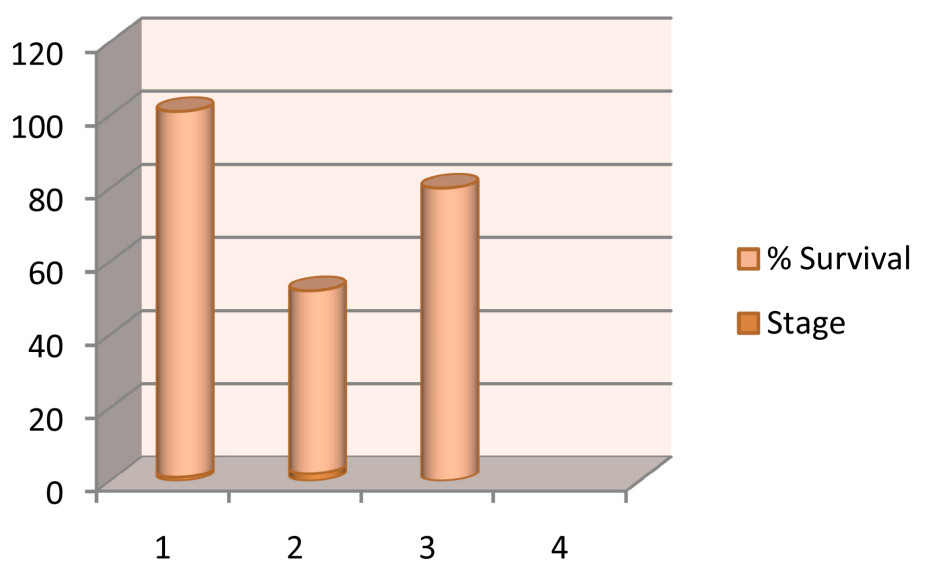

Figure 1. Graphical representation of \% survival in different stages of neuroblastoma in our study.

In Stage 1, no pre op. chemotherapy was given. Tumor was excised in total. Post-operatively no adjuvant therapy was given. Both patients are alive till date.

In Stage 2A, patients were operated and received post-operative chemotherapy. One patient is alive and disease free. Other patient died in post-op. period while on chemotherapy.

Patients in Stage 4S were operated after receiving pre-op radiotherapy of 500 - 1000 rads and adjuvant chemotherapy. One patient expired in follow up while four patients are still alive.

We have achieved 100\% survival rate in Stage 1, 50\% in Stage 2 and $80 \%$ in Stage 4S.

\section{Conclusions}

Pediatric tumors form a small proportion of all cancers; however, they are important in understanding the importance of neoplastic growth, evolution of cancer therapy and its social impact is much more than anticipated; besides it results in loss of many more productive years of life. Gratifying advance in the treatment of pediatric cancers for the past three decades has resulted in decrease in annual mortality by $36 \%$.

However, much inference about survival in pediatric malignancies cannot be committed upon because of the less number of patients which were studied and followed up only for a short period of time.

\section{References}

[1] Oldham, K.T., Colomboani, P.M. and Foglia, R.P. (1997) Surgery of Infants and Children. Scientific Principles and Practice, Lippincott-Raven, Philadelphia, 537-548, 549-565.

[2] Ghai, O.P., Gupta, P. and Paul, V.K. (2000) Malignancies in Childhood, Essential Paediatrics. 5th Edition, $462-474$. 
[3] Young, G., Toretsky, J.A., et al. (2000) Recognition of Common Childhood Malignancies. American Family Physician, 61, 2144-2151.

[4] Malpas, J.S. and Freeman, J.E. (1974) Blood and Neoplastic Diseases: Solid Tumours in Children. British Medical Journal, 4, 710-713. http://dx.doi.org/10.1136/bmj.4.5946.710

\section{Submit or recommend next manuscript to SCIRP and we will provide best service for you:}

Accepting pre-submission inquiries through Email, Facebook, LinkedIn, Twitter, etc.

A wide selection of journals (inclusive of 9 subjects, more than 200 journals)

Providing 24-hour high-quality service

User-friendly online submission system

Fair and swift peer-review system

Efficient typesetting and proofreading procedure

Display of the result of downloads and visits, as well as the number of cited articles

Maximum dissemination of your research work

Submit your manuscript at: http://papersubmission.scirp.org/ 